Емир Кустурица

Андрићев институт

811.163.41:005.71(497.6)

Андрићград

\title{
СРПСКИ ЈЕЗИК И ЋИРИЛИЦА ДАНАС
}

Одговорност је српске државе и српског народа да се сачувају српски језик и ћирилица. У Андрићевом институту отворићемо Одјељење за српски језик, у намери да има утицај на културу и науку не само у Републици Српској, вец и шире.

Кључне речи: српски језик, ћирилица, Андрићев институт, Одјељење за српски језик.

Кад уђемо у срце српског проблема и кад се вратимо двјеста година уназад, кад се вратимо Темишварском договору наших владика, дакле првом сусрету представника наше нације, уочавамо једну ствар која је карактеристична за све касније периоде. У вријеме када је Француска имала отприлике седамнаест посто варошана, а Енглеска око двадесет, ми смо имали два посто. И ту се намеће проблем, који заправо производи проблеме не само у том централном питању нације, који се зове језик, него и у дјеловању онога што се касније називало елита. У нашем случају, у том историјском обрту који се десио између Првог и Другог устанка, односно у првој држави коју смо добили почетком двадесетог вијека, постојао је недостатак онога што се код свих народа називало племство. Наша елита, односно наше племство, било је неидентификовано ако није у сфери свештенства. У том прекиду који је произвела Отоманска империја код нас не 
постоји стабилна основа за стварање нације јер, уосталом, по неким дефиницијама, нација је само њена елита, односно њено племство.

Кад узмемо у обзир како се заправо неуротично развијала наша историја, ми можемо да говоримо о одређеним територијама и мислим да је ту језгро главног проблема. На пример, кад погледамо двјеста година уназад или мало раније, ми можемо да констатујемо да Шумадије није ни било, како каже Екмечић, односно ми можемо да говоримо о коришћењу српског језика више у Босни и Херцеговини, гдје је било више од милион и двјеста хиљада становника 1800. године и више српског језика него у Београдском пашалуку из којег је заправо кренуло то надахнуће да се ствари мијењају, да се крене у револуцију, односно у устанке. Мислим да је судбина тог језика управо у тој територијалној распарчаности и она у модерним условима даје следећи резултат: кад се задесимо у Бањалуци и укључимо телевизију, ми најчешће слушамо српски језик који се говори распоредом глагола и инфинитива који праве Хрвати. И то са великим поносом! Имао сам препирку са неким професорима са Филолошког факултета из Бањалуке којима сам рекао да је непримјерено да се инфинитив ставља на крају реченице, јер је то хрватска имитација њемачког. Е, сад, а ко сам ја ко задрто тражи да се негдје остане у оквиру те ограде у којој језик може да се разиграва и развија? Језик је жив, он трпи и туђице и тако даље. Имамо примјера да, рецимо у Финској, џи-пи-ес нема своје оригинално име. Дакле, постоји оптимализација језика који не прима туђице уопште, који не дозвољава да се оне развијају ни на једној основи. Ми то не можемо управо зато што је наша историја везана за све врсте утицаја или, како Екмечић каже, нема те колонијалне силе која овдје није направила штету и убацила ту капсулу која једног дана минира.

Имамо језик који институционално не брани готово нико. Имамо Академије и у Бањалуци и у Београду које, 
у ствари, дјелују научно, а то је оно што је најмање популарно данас. Одбрана тог језика не може никако да буде изведена у потпуности и до краја. Мора се ући у коријен и институције које јавно говоре кориговати, односно да по новим неким правилима, и то што дјелује као нација, а у оквиру језика, и са свим сазнањима о тим тешкоћама, напредује.

Има још једна ствар која је, колико видим, најновија. Тај језик је постао инспирација. Уопште тај наш лингвистички код је постао политички лингвистички код и он рађа нове језике. То су језици који потпуно теку из једне те исте културе говора и који настају и који се, захваљујући Европској унији и свим неманима овог времена, успостављају као правило које ми морамо да поштујемо. Како се то решава - нисам сигуран да знам. Али знам да ћемо ускоро отворити у Андрићевом институту Одјељење за српски језик. То Одјељење би морало да има утицај на ТВ Дневнике у Републици Српској. И на Дневнику РТРС, али и другим у Републици Српској изговарају се све те конструкције реченица које задиру у оно што ми нисмо. На тим границама, на тим ободима, губи се наш књижевни језик за који постоје професионални писци који га разваљују. Постоји и та људска потреба која није само наша карактеристика, да све што је старо треба да се мијења, као што се стари шпорет шездесетих мијењао за онај електрични, у којем је било пуно азбеста, па се касније установило да смо због тога живјели пуних двадесет година нездраво. Тако је и у овом малочас поменутом случају.

Ако поступамо научно, морамо да имамо идеју шта наука производи у крајњој консеквенци, односно како се српски језик штити у првој линији боја, а то је тамо гдје се највише говори, гдје се највише брбља. То су телевизије, радији и све оно што оставља утисак и што дјеца заправо уписују у подсвјест као идеју о томе како они 
треба да говоре. Тај се језик квари по природи ствари. Тај језик добија дневно безброј топонима, нових ријечи, које информатички свијет производи, па онда ми који говоримо том неком источно-херцеговачком верзијом ијекавског говора испадамо мало анахрони. Ја схватам, пошто и пишем, да је језик и питање мелодичности и музикалности. Јер ако се човјек који напише једну реченицу чврсто држи свега о чему говори наука, онда тај језик постаје мало умртвљен, па му је неопходно додавати нешто што га оживљава. Шта га то оживљава? Сигурно не нешто што можемо прочитати у књигама него нешто што нас копча са временом у којем живимо. У свим тим проблемима мислим да може да се, између осталог, тражи и проблем нашег језика, наша је обавеза да га враћамо и да му државно не дамо да пропадне, као што је, врло очито, изложен пропадању и као што многи, развлачећи на те политичке, лингвистичке тачке, том језику смањују вриједност.

Добро је да се код нас појављују млађи писци који, чак и кад узимају у обзир и говорни језик новонастали, попут Владимира Кецмановића чији роман Осама својом структуром још једном доказује једну феноменалну ствар, да један Србин може да исприча причу о Србима и муслиманима у Босни боље него што су они у стању да ураде. То је можда једна основа о којој се може причати. Заправо, наша приврженост истини може да буде опасна у ово вријеме пост-истине, али ми смо у обавези да је формулишемо као позитивну истину из које тај језик, кад закорачимо у одбрану, представља позитиван ефекат. Ми имамо младе књижевнике. Нема их много, немају велики утицај, јер су политичари покупили сав јавни утицај, али заправо сав тај позитивни утицај треба тражити и у књижевности, у ономе што млади даровити писци данас пишу.

Модерна српска држава настала је уз отежавајућу околност да је прво српски народ живио на више територија и да је језик од Вука наовамо стизао са разних тачака, 
али је његова жилавост евидентна. Ми смо, уосталом, у деветнаестом и двадесетом вијеку имали литературу која је обитавала на највишим тачкама и која је „заправо“ била легитимација заштите тог језика. Кад гледамо наше комшије и тај политички језик који је уведен или те нове језике, ту онда постоји једна озбиљна мана непостојања тих писаца, нити је, што би рекли компјутераши, „бекапован“ у стварној вриједности. Он тако лебди између телевизијских произвољности и нечег што не може бити утврђено у језику, а да при томе није израз веома озбиљне литературе. 
Emir Kusturica

The Andrić Institute

Andrićgrad

\section{SERBIAN LANGUAGE AND CYRILLIC TODAY}

The responsibility of the Serbian state and the Serbian nation is to preserve the Serbian language and Cyrillic. In the Andric Institute, we will open Department for the Serbian Language, with the intention to have an impact on culture and science, not only in the Republic of Srpska, but also wider.

Key words: Serbian Language, Cyrillic, The Andrić Institute, Department for the Serbian Language. 